DOI https://doi.org/10.30525/978-9934-26-182-4-12

\title{
ОПЕРАТИВНІ МЕТОДИ КОРЕКЦІЇ СИНДРОМУ ВЕРХНЬОЇ ПОРОЖНИСТОЇ ВЕНИ У ХВОРИХ ІЗ МІСЦЕВОРОЗПОВСЮДЖЕНИМИ ПУХЛИНАМИ ТИМУСА
}

\author{
Мінухін Д. В. \\ кандидат медичних наук, \\ дочент кафедри хірургії № 1
}

Харківський національний медичний університет

Кріцак В. В.

кандидат медичних наук,

дочент кафедри хірургї̈, нормальної та топографічної анатомії

Навчально-науковий медичний інститут

Національний технічний університет

«Харківський політехнічний інститут»

Мінухін Б. Д.

студент II курса

Харківський національний медичний університет

м. Харків, Україна

Синдром верхньої порожнистої вени (СВПВ) був вперше описаний W. Hunter в 1757 p $[1,4,5]$. Зменшення кровотоку в системі верхньої порожнистої вени (ВПВ) призводить до зниження об'єму венозної крові в правому передсерді, що обумовлює ряд клінічних ознак і симптомів, таких як розширення вен шиї, набряк верхніх кінцівок, ціаноз, головний біль, задишка, кашель, дисфагія $[2,3,7]$. Порушення кровотоку може бути викликано зовнішньої компресією, прямою пухлинною інвазією, тромбозом або неефективним венозним поверненням внаслідок захворювань, які залучають праве передсердя або безпосередньо просвіт судини. Протягом часу основна роль в етіології даного синдрому змістилася в сторону місцеворозповсюджених пухлин середостіння, таких як тимоми $[5,7]$. До $85 \%$ випадків СВПВ розвиваються внаслідок первинного або вторинного пухлинного ураження, у 73-85\% випадках внаслідок місцеворозповсюджених тимом $[1,4,7]$.

Мета роботи: Продемонструвати можливість і технічні особливості оперативних методів корекції СВПВ обумовлених місцеворозповсюдженими пухлинами тимусу. 
Материалі і методи. Дослідження являє собою аналіз даних спостереження 56 хворих із місцеворозповсюдженими тимомами, що ускладнилися СВПВ за період з 2014 по 2020 рр., що лікувалися на базі ДУ «Інститут загальної та невідкладної хірургії ім.В.Т.Зайцева НАМН України». До групи порівняння увійшло 30 пацієнтів з СВПВ в лікуванні яких використовувалися загальноприйняті методики лікування, в основну групу ввійшло 26 пацієнтів, в лікуванні яких використовувалися нові, розроблені нами обхідні шунтуючі операції.

На передопераційному етапі всім пацієнтам були виконані стандартні діагностичні дослідження, що дозволяють оцінити поширеність пухлинного процесу в середостінні і функціональні резерви: мультиспіральна комп'ютерна томографія (МСКТ) органів грудної клітки і черевної порожнини, комплексне ультразвукове дослідження (у тому числі УЗД середостіння), електрокардіографія, ехокардіографія, спірометрія.

Після ретельного обстеження та оцінки операційного ризику хворі груп дослідження були оперовані. Структура оперативних втручань представлена наступним чином: 1) Експлоративні втручання з біопсією 6(20\%) тільки у хворих групи порівняння; 2) Декомпресивні циторедуктивні втручання - 4(13,3\%) тільки у хворих групи порівняння; 3$)$ Обхідні шунтуючі операції - 12(46,2\%) тільки у хворих основної групи; 4) Розширена тимтимомектомія 3 резекцією плечеголовної вени $9(34,6 \%)$ у хворих основної групи та $13(43,3 \%)$ у хворих групи порівняння; 5) Розширена тимтимомектомія з резекцією ВПВ - 5(19,2\%) у хворих основної групи та 7(23,4\%) у хворих групи порівняння.

\section{Результати та їх обговорення.}

Принциповим у веденні періопераційного періоду хворих на місцеворозповсюджені тимоми з розвитком СВПВ є забезпечення адекватного судинного доступу для введення лікарських речовин, що забезпечувалось шляхом катетеризації стегнових вен або внутрішньоартеріальним введенням препаратів. У хворих основної групи, у яких видалити пухлину технічно було не можливо, виконували обхідні венозні шунти, які дозволяли скорегувати СВПВ. За нашими спостереженнями ці операції переносилися хворими значно легше. Операцію обхідного шунтування обов'язково доповнювали циторедукцією. У наших спостереженнях застосовані аурікулояремні шунти (зліва, зправа) та аурікулопідключичні шунти. Так як «улюбленою» локалізацією інвазивних тимом являється лівобічний тип ураження, тому лівобічні шунти були використані частіше при корекції СВПВ.

У 5 випадках обхідний аурікулояремний шунт використовували, як допоміжний етап при радикальних видаленнях місцеворозповсюдже- 
них пухлин тимусу. Видалення пухлини з інвазією в ВПВ без попереднього обхідного шунта, з нашої точки зору, є помилкою, яка може стати причиною летального результату. Перетинання ВПВ або гострий iіi тромбоз при виділенні пухлини призводить до стрімкого підвищення центрального венозного тиску 3 витікаючими 3 цього наслідками. В окремих випадках може мати місце відрив навколопухлинного тромбу або пухлинної тканини з їх міграцією до правих відділів серця і розвитком тромбоемболії легеневої артерії.

Враховуючи те, що усі хворі відносилися до III-IV клінічної стадії розповсюдженості пухлинного процесу за Masaoka-Koga, в післяопераційному періоді пацієнтам проводилася дистанційна променева терапія, за дрібно-протяжною схемою з опромінюванням фракціями по РВД (разова вогнищева доза) $=2$ Гр 1 раз на тиждень до СВД (сумарна вогнищева доза) $=40-45$ Гр (при радикальних втручаннях) та РВД=2 Гр 5 разів на тиждень до СВД 60-70 Гр. Хіміотерапевтичне лікування застосовувалося в комбінації з променевою терапією у 11(9,7\%) хворих після циторедуктивних та експлоративних втручань.

Післяопераційна летальність в досліджувальних групах склала: $4(13,3 \%)$ - група порівняння та 1(3,8\%) - основна група. Причинами післяопераційної летальності стали ускладення: міастенічний криз 1(1,8\%); пневмонія - 1(1,8\%), інфаркт міокарда - 1(1,8\%), тромбоемболія легеневої артерії-2(3,6\%).

\section{Висновки.}

1. Синдром верхньої порожнистої вени у хворих на місцеворозповсюджені тимоми - невідкладний стан, хірургічна корекція якого повинна бути індивідуалізована 3 огляду на анатомо-топографічні особливості ураження ВПВ.

2. Обов'язковою умовою ведення періопераційного періоду у даної категорії хворих являється наявність адекватного судинного доступу до системи нижньої порожнистої вени.

3. Першим обов'язковим етапом виконання радикальної операції у хворих на місцеворозповсюджені тимоми з ураженням ВПВ слід вважати накладення обхідних аурікулояремних та аурікулопідключичних шунтів.

\section{Література:}

1. Бойко В.В., Краснояружський А.Г., Ткаченко В.В. Діагностика і тактика лікування новоутворень середостіння. Міжнародний медичний журнал. 2015. №4. С. 28-32. 
2. Калабуха I.А., Маєтний С.М. Доброякісні пухлини середостіння: клініка, діагностика, хірургічне лікування. Клінічна хірургія. 2015. № 12. C. 33-35.

3. Кравченко Р.Ю. Новоутворення середостіння. Помилки в діагностиці та їх вирішення. Український медичний часопис. 2021. №3(143). C. 1-3.

4. Паршин В.Д., Мирзоян О.С., Титов В.А., Паршин А.В., Зулуфова И.Д. Хирургическое лечение гигантской тимомы, осложненной компрессионным синдромом органов груди. Хирургия. Журнал им. Н.И. Пирогова. 2019. № 12. С. 132-136. https://doi.org/10.17116/ hirurgia2019121132.

5. Пикин О.В., $\quad$ Трахтенберг А.Х., Колбанов К.И., $\quad$ Глушко В.А., Казакевич В.И., Амиралиев А.М., Вурсол Д.А., Кирсанова О.Н. Циркулярная резекция верхней полой вены без протезирования у больных с опухолью средостения, осложненной синдромом медиастинальной компрессии. Онкохирургия. 2013. №5(2). С. 60-6.

6. Odaka M., Tsukamoto Y., Shibasaki T., Mori S., Asano H., Yamashita M., Morikawa T. Surgical and oncological outcomes of thoracoscopic thymectomy for thymoma. J Vis Surg. 2017. N3. P. 54. doi: $10.21037 /$ jovs.2017.03.18

7. Venuta F., Rendina E.A. Superior vena cava resection and reconstruction. Eur J Cardiothorac Surg. 2012. N.41(5). P. 1177-8. doi: 10.1093/ejcts/ ezr266. 